Foster, M. D., Hennessey, E., Blankenship, B. T., \& Stewart, A. (2019). Can "slacktivism" work? Perceived power differences moderate the relationship between social media activism and collective action intentions through positive affect. Cyberpsychology: Journal of Psychosocial Research on Cyberspace, 13(4), article 6.

\title{
Can "Slacktivism" Work? Perceived Power Differences Moderate the Relationship Between Social Media Activism and Collective Action Intentions Through Positive Affect
}

\author{
Mindi D. Foster ${ }^{1}$, Eden Hennessey ${ }^{1}$, Benjamin T. Blankenship², \& Abigail Stewart ${ }^{3}$ \\ ${ }^{1}$ Wilfrid Laurier University, Waterloo, Ontario, Canada \\ ${ }^{2}$ James Madison University, Harrisonburg, Virginia, USA \\ ${ }^{3}$ University of Michigan, Ann Arbor, Michigan, USA
}

\begin{abstract}
We argue that the often-used critique of social media activism as merely a 'feel-good' mechanism can be countered by conceptualizing social media activism as a necessary type of collective action (i.e., consensus mobilization), incorporating theory on the benefits of positive feelings for activism, and by examining how power may affect these relationships. Women from two different samples (MTurk and university) were randomly assigned to recall a highversus low-power experience, view real-world events of sexism, and then complete questionnaires assessing endorsement of social media activism, positive affect, and collective action intentions. A dual moderated mediation analyses at the second stage of mediation showed equivalency across two samples, at which point the single moderated mediation model was tested on the combined sample. The model was significant, such that among those in the high-power condition, endorsing social media activism was associated with greater positive affect, which in turn predicted greater collective action intentions. Among those in the low-power condition, however, this indirect effect was not significant. This study provides counter-evidence to the 'slacktivism' critique, contributes to theories of collective action, power and their integration, and identifies a possible intervention to enhance the effectiveness of social media activism.
\end{abstract}

Keywords: Social media; collective action; slacktivism; power; activism; sexism

\section{Introduction}

"Slacktivism" (Mozorov, 2009), "armchair activism" (Gladwell, 2010), and "hashtag activism" (Augenbran, 2011) are labels reflecting initial criticisms of social media activism. These criticisms continue even after the visibility and impact of hashtags such as \#BlackLivesMatter, \#MeToo and \#NeverAgain. Articles on blogs (e.g. Feldman, 2017) and traditional media outlets (e.g., Funnell, 2017; Willingham, 2018) demonstrate the discourse that continues to be presented by the general public, and for the general public's consumption whereby behaviors like the click of a 'like' button (e.g., Feldman, 2017; Willingham, 2018), joining a Facebook group (e.g., Mozorov, 2009) or re-tweeting a hashtag (e.g., Augenbran, 2011; Gladwell, 2010) are denounced. These criticisms assert that social media activism is ineffective for social change, and instead serves only to make us feel good. Inherent in this argument are several assumptions: (1) social media activism is understood only as the click of a button; (2) as such a small action, it must be ineffective; and, (3) that 'feeling good' does not play a role in activism. In contrast, we argue that (1) social media activism can be conceptualized as a necessary type of collective action, namely consensus mobilization, and as such, need not be discounted as effective activism, (2) positive feelings have an important role in promoting 
activism, and (3) there are conditions under which the positive feelings that result from social media activism may be more likely to promote future activism.

\section{Defining Social Media Activism}

Perhaps one reason social media activism has been considered ineffective is that often, the first thing people envision when they hear about activism is a large protest in response to social injustice (e.g., the 2017 Women's March). Indeed, one the most famous criticisms of social media activism contrasted it with a group-based, highrisk action such as sitting at the Woolworth's counter to protest racial segregation in 1960 (Gladwell, 2010). Not surprisingly, clicking a 'like' button or re-tweeting a hashtag seems to pale in contrast to such a notable collective action. However, theorists broadly define collective action as intent-based, rather than merely one form of action; it is any action that serves to benefit group status, whether that action is taken individually or with a group (Lalonde, Stroink, \& Aleem, 2002; Wright, 2009; Wright, Taylor, \& Moghaddam, 1990). Individual behaviours can be considered collective action if they are collectively intended, and/or if thoughts/actions are guided by group rather than personal interests (Louis, 2009; van Zomeren \& lyer, 2009). As such, operational definitions of offline collective action have traditionally included not only high risk, high effort, and group-based behaviors such as protest, but also low risk and effort individual behaviors such as signing a petition, writing a parliamentarian or voting (e.g., Foster \& Matheson, 1995; Kelly \& Breinlinger, 1995; Louis, 2009). By considering the wider range of collective actions that exist, and further recognizing that some of those types of collective actions have social media counterparts (Bennett \& Segerberg, 2012; Brunsting \& Postmes, 2002; Foster, 2015; Halupka, 2016; Postmes \& Brunsting, 2002), then their similarities become more apparent, and the potential effectiveness of social media activism comes into view.

In particular, we focus on consensus mobilization types of actions that occur when "a social movement tries to obtain support for its point of view. It is directed towards influencing knowledge, beliefs and attitudes" (P. G. Klandermans, 1984, p. 107). When individuals attempt to inform others that 'a certain state of affairs is unacceptable and can be changed' (B. Klandermans \& Oegema, 1987, p. 519), they are participating in consensus mobilization. Consensus mobilization is referred to as the necessary first step in the participation process (B. Klandermans \& Oegema, 1987; P. G. Klandermans, 1984; Snow, Rochford, Worden, \& Benford, 1986); an individual will not likely participate in a social movement without at least agreeing the movement's goals are worthy and achievable. Pre-internet forms of consensus mobilization have included letter-writing (Foster \& Matheson, 1995; B. Klandermans, 1997) and signing a petition (Kelly \& Breinlinger, 1995; Louis, 2009). Before the appearance of social media sites such as Facebook and Twitter, Postmes and Brunsting (2002; see also Brunsting \& Postmes, 2002) argued that the Internet was well-suited for these "persuasive actions" such as emailing others and online petitions. With the incarnation of social media, this form of activism has been most recently conceptualized as "information activism," which specifies increasing degrees of engagement: information gathering and spreading, providing solidarity and then assistance to protestors, and influencing others' opinions (Halupka, 2016). Various social media campaigns have been used in these ways. For example, the global hashtag, \#MeToo, called attention to and gathered support for victims of sexual assault (King, 2018), akin to Halupka's (2016) information activism techniques of spreading information and providing solidarity. Thus, if social media activism is viewed as a technical variation of consensus mobilization, it can also be considered an essential first step in mobilization of future action.

Indeed, there is cumulating evidence to support the effectiveness of various types of social media activism. For example, activists and non-activists consider both online and offline forms of activism to be equally effective (Brunsting \& Postmes, 2002; Postmes \& Brunsting, 2002). Consistent with this idea, Milošević-Đorđević and Žeželj (2017) tested whether online and offline actions would be represented by a one- or two-dimensional model and found that a unidimensional model of activism better fit the data, suggesting that online and offline activism are not distinct concepts. Moreover, accumulating research shows that more online activism predicts more offline activism (e.g., Boulianne, 2009; Conroy, Feezell, \& Guerrero, 2012; Fatkin \& Lansdown, 2015; Lee \& Hsieh, 2013, Vaccari et al., 2015; Vitak et al., 2011). Together, these studies support the notion that social media activism can promote larger scale collective actions.

However, the above studies have not examined these issues within a specific context of women acting against sexism. Indeed, while men's participation in activism for women's rights is important for ultimate changes in attitudes and the status quo, this research focuses on women alone. There are several reasons why there is merit 
in studying women in and of themselves. First, one of the unique experiences for women is that they can experience discrimination from a wide variety of sources, some of which are often unexpected. Not only does discrimination against women endure on an economic basis (e.g., women still earn .87 cents on the male dollar; Statistics Canada, 2018), but women often live with and love (fathers, sons, romantic partners) members of the group that have historically discriminated against their own group, thereby experiencing discrimination from trusted individuals with whom they have intimate relationships (e.g., Ayres, Friedman, \& Leaper, 2009; Foster, 2013). Moreover, compared to women, men are more often the perpetrators of gender discrimination (Brinkman \& Rickard, 2009; Glick et al., 2000; Gruber, 1998) and less likely to participate in offline activism on behalf of women (Radke, Hornsey, \& Barlow, 2018; Stake, 2007; White, 2006; R. Williams \& Wittig, 1997). Thus, if women are the targets of pervasive discrimination, and less likely to be helped by men to change this, it is especially important to understand the conditions under which the targets of discrimination (in this case, women) will act for themselves.

Granted, men do indeed act as outgroup allies of women's rights. For example, bystander programs that teach men to speak up against sexual violence are beneficial for reducing male rape myth acceptance (Baynard, Moynihan, \& Plante, 2007; A. L. Stewart, 2014). At the same time however, research has also shown that participation by outgroup allies can nevertheless lower the disadvantaged group member's participation in activism, because it reduces the perceived inequality of status, and legitimacy of taking action (Becker, Wright, Lubensky, \& Zhou, 2013; Droogendyk, Wright, Lubensky, \& Louis, 2016; Wright \& Lubensky, 2009); if two groups are working together and getting along, the very reason for activism may indeed appear unnecessary. As such, if outgroup allies can potentially undermine the disadvantaged group's activism, it is also important to understand the processes, conditions and spaces in which the disadvantaged group (in this research, women) will feel empowered to act by and for themselves.

In fact, one of these spaces is social media; it has been described as a "counter-space" for women (e.g., Case \& Hunter, 2012; S. Williams, 2015). The term counterspace had originally been in reference to university students facing racial discrimination; they created safe spaces for themselves to function without fear and anticipation of stereotypes and racism, in contrast to what they faced in traditional spaces (e.g., classroom, dorms, traditional fraternities/sororities) (Solórzano, Ceja, \& Yosso, 2000). Counter-spaces have also been studied among multiple marginalized groups (see Case \& Hunter, 2012 for a review) and feminist scholars have described social media in particular as a counter-space for activism among women. Using social media for information activism allows women to call attention to issues that traditional media and hierarchical structures have historically disregarded (Eagle, 2015; Jackson, 2018; Linder, Myers, Riggle, \& Lacy, 2016; S. Williams, 2015). To that end, women have utilized information activism to such an extent that it is referred to as "hashtag feminism" (Clark, 2016; Conley, in press; Mendes, Ringrose, \& Keller, 2018). Since Arab Spring, when women began to utilize Facebook and Twitter for passing on information about protests, more so than men (Tufekci \& Wilson, 2012), women's global use of hashtag feminism has exploded. In India, \#BoardtheBus was used by women to call attention to lack of safety on public buses (Eagle, 2015). In the United Kingdom, \#EverydaySexism, was used for women to report their experiences with sexism in the public spaces they navigate every day (e.g., walking down the street, parks, transit etc.) (Bates, 2014). Among the most popular, \#MeToo began in the United States, whereby women attempted gather the support they could not receive from traditional structures (the legal system, employers, etc.), regarding issues of sexual assault (Mendes et al., 2018). Online and social media outlets have continued to be an activist platform of choice for women more so than men (Duggan \& Brenner, 2013; Murthy, Gross, \& Mensavalle 2016; Pew Research Center, 2014; Sutton \& Pollock, 2000; Twenge, 2017).

At the same time however, the digital space can be a paradoxical experience for women; cyberbullying is perpetrated against girls and women more often than boys and men in the United States (Duggan, 2014), Canada (Hango, 2016) and the European Union (European Institute for Gender Equality, EIGE, 2019). Moreover, cyberbullying has different consequences for girls versus boys; recognizing the digital space as unsafe can result in girls and women limiting their own participation online (Jackson, 2018; EIGE, 2019; Mendes et al., 2018) whereas boys tend to ignore their own experiences with cyberbullying (EIGE, 2019). This suggests a difficult cycle for women: silencing from public spaces and traditional structures led to the use of counter-spaces, but backlash in these counter-spaces can result in the very silencing they were meant to reduce. As such, it is crucial to understand how women navigate social media activism and the conditions under which it can predict future collective action intentions within a context of everyday sexism. 
Hypothesis 1: It was expected that the more women endorse engaging in information activism responses on social media, the higher future collective action intentions they will report.

\section{Positive Affect and Activism}

A second purpose of this paper is to address the role that positive emotions play in explaining the relationship between social media activism and collective action. Inherent in the criticisms that social media activism serves only to make us feel good, is the notion that 'feeling good' serves no purpose in motivating activism. However, from a psychological perspective, there is theoretical support for those positive feelings as a means of enhancing activism. For example, it is well-established within learning theory (Skinner, 1971) that behaviors followed by positive consequences are repeated, whereas those followed by negative consequences are avoided. As such, it would be expected that if people feel good after participating in social media activism (positive consequence), then intentions to participate in other forms of activism would be more likely.

More specific to activism, recent theoretical extensions of social identity theory (Tajfel \& Turner, 1986), namely the elaborated social identity model (ESIM; Drury \& Reicher, 1999) and the dynamic dual pathway model (DDPM; van Zomeren, Leach, \& Spears, 2012) focus on the dynamic nature of activism, whereby feedback loops exist between collective action and its antecedents and consequences. One of these loops is between the individual's cost-benefit analysis of whether activism will be beneficial to them as individuals; and, positive affect is one of these benefits (van Zomeren et al., 2012). If people feel good after activism, this individual benefit would feed back into deliberations about whether to participate in future action. Theoretically then, if people feel positive after participating in social media activism, these positive consequences may push the cost-benefit analysis to the 'plus side,' enhancing the likelihood of engaging in future, more effortful, larger-scale activism.

Research on the role of positive emotions in the effectiveness of social media activism is mixed. Schumann and Klein (2015) showed that online actions could derail offline actions, but not because participants were simply satisfied by feeling good about themselves. Instead, offline actions decreased because participants believed their actions were effective in enhancing the group's success, thereby negating the need for future action. Schumann, Klein and Douglas (2012) showed that participants who used the Internet to share information about improving the environment and how to get involved, reported feeling more personally empowered to impact collective actions for the environment (e.g., "My impact on what happens during this action is large", p. 83), which in turn, increased their willingness to participate in future offline actions such as a demonstrations. Thus, although these studies did not directly examine how feeling good about oneself (versus the group) after social media activism may play a role in promoting larger-scale collective actions, Schumann and colleagues' work suggests that feeling positively may in part explain the relationship between social media activism and offline activism. One study (Foster, 2015) did examine positive feelings about oneself, showing that tweeting a collective response after being exposed to sexism increased psychological well-being and decreased negative affect. However, whether these positive feelings would in turn, predict offline collective actions was not addressed. Thus, a second purpose of this paper is to examine whether positive emotions following social media activism would mediate the relationship between social media activism and future collective action intentions.

Hypothesis 2: It was hypothesized that the relationship between social media activism and collective action (Hypothesis 1) would be at least partially mediated by positive feelings, such that, the more women endorse engaging in social media activism, the more positive affect they would report, which in turn would predict greater collective action intentions.

\section{Power and Collective Action}

Finally, even if social media activism increases the likelihood of future collective actions through positive feelings, there are likely to be conditions under which these relationships are strengthened or weakened. This study focused on power, given one of the most consistent predictors of collective action is a sense of group efficacy, or collective power, namely the belief that the group's action can impact social change (Cohen-Chen \& van Zomeren, 2018; Hornsey et al., 2006; Mummendey, Kessler, Klink, \& Mielke, 1999; van Zomeren et al., 2012; van Zomeren, Postmes, \& Spears, 2008). However, group efficacy is still only a moderate predictor of collective action intentions and behaviour (van Zomeren et al., 2008). This leaves open the possibility that other aspects of efficacy/power, 
such as individual-level beliefs about how powerful one is, may also play a role. Indeed, it is the individual who ultimately makes the decision to participate in the action. Although individual-level variables as predictors of collective action have received criticism (Schrager, 1985), ignoring individual psychological motivations of collective action may not be appropriate either (Duncan, 1999; Duncan \& Stewart, 2007), especially given that digital forms of collective action can now be taken individually and privately. As such, a third purpose of this paper was to examine an individual-level conceptualization of power.

Although definitions of power differ depending on the discipline and/or the research question (see Keltner, Gruenfeld, \& Anderson, 2003 for a review), we focused on the definition of power as one's ability to control resources (Galinsky, Gruenfeld, \& Magee, 2003; Keltner et al., 2003). This definition was chosen since it is consistent with previously predominant theories of activism that argued collective action will occur when the necessary psychological, social, or tangible resources are present (McCall, 1970; McCarthy \& Zald, 1977; Olson, 1965; Smelser, 1964; Tilly, 1978). One's ability to control resources enhances a variety of approach-based cognitions, feelings and behaviors that stimulate action (e.g., approach goals, increased heart rate), whereas without the resources to act, people's behavioral repertoire resembles inhibition (Keltner et al., 2003). Interestingly, research shows the impact of power is not on affect, but on action (e.g., Fast, Gruenfeld, Sivanathan, \& Galinsky, 2009; Galinsky et al., 2003; Weick \& Guinote, 2008). That is, the ability of power to enhance action is not because feeling powerful makes us feel good, but because it directly impacts action. Under this logic, it is less likely that feeling powerful would strengthen the ability of social media activism to increase positive feelings, but rather, strengthen the ability of positive affect to promote greater collective action.

Hypothesis 3a: It was expected that the indirect effect of social media activism on collective action intentions through positive affect (Hypothesis 2) would be moderated by power, such that the indirect effect would be strongest among those in the high-power condition, versus those in the low-power condition.

Hypothesis 3b: It was further expected that power would moderate the indirect effect at the second stage of mediation (between positive affect and action), rather than at the first stage of mediation (between social media activism and positive affect) (See Figure 1).

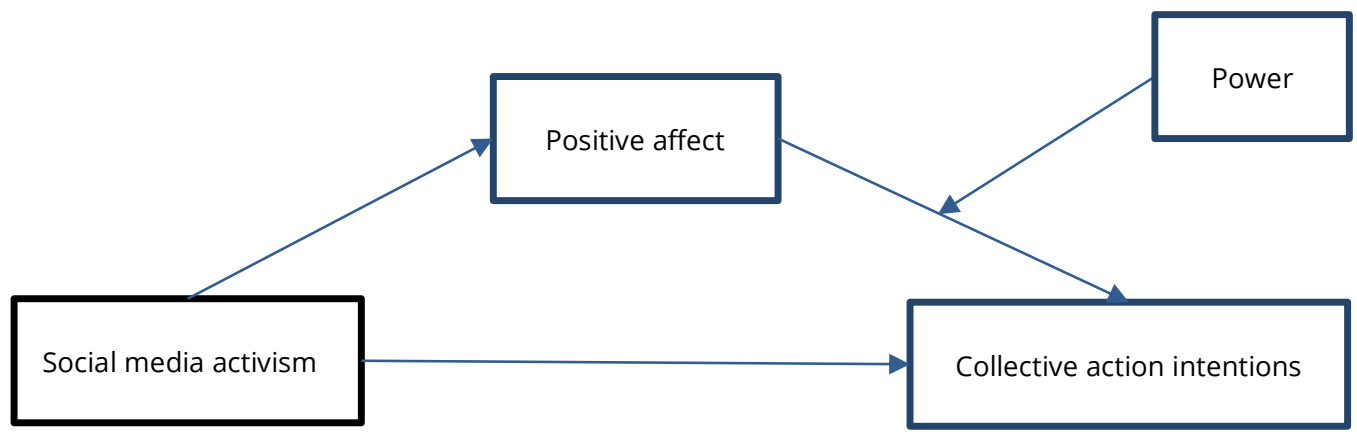

Figure 1. Hypothesized moderated-mediating model at the second stage of mediation.

\section{Method}

\section{Participants}

To assess the generalizability of the hypothesized model, participants were recruited from both a nonundergraduate sample and an undergraduate sample. The non-undergraduate sample was recruited from Amazon's Mechanical Turk (MTurk) for payment of \$.50. Using TurkPrime, adults (18+) who had completed at least 100 surveys in the past with an $80 \%$ acceptance rate were recruited. Data from 200 heterosexual women were collected, ${ }^{1}$ and the final MTurk sample $\left(M_{\text {age }}=39.2, S D=14.3\right)$ was 128 , due to failure of three of the four attention 
checks. There was no relationship between being excluded from the study, and the experimental condition, $\chi^{2}(2)$ $=.131, p=.94$. Self-reported race/ethnicity was 78.9\% White/Caucasian, 7\%/ Black/African-American, $4.7 \%$ Asian/Asian-American, 3.9\% Latino/Latina/Hispanic, 3.9\% Biracial, .8\% Middle Eastern, and .8\% Native American.

The second sample consisting of undergraduate women was collected using Wilfrid Laurier University's undergraduate psychology participant pool $(N=181)$. The mean age was 20 years $(S D=3.4)$. Self-reported race/ethnicity was 66.9\% White/Caucasian, 8.3\% South Asian, 5.5\% Chinese, 9.7\% Multi-racial, 2.8\% Black, 1.7\% Arab, 1.7\% Korean, 1.7\% South East Asian, 1.1\% Hispanic, and .6\% West Indian. Race/ethnicity categories differed across the two samples as the MTurk questionnaire followed American norms, whereas the university questionnaire followed Canadian norms. All data were collected from 2015-2017.

\section{Procedure}

To reduce demand characteristics, the study was vaguely described as a questionnaire on how beliefs about power and fairness are different when referring to the self, versus our social groups, as well as past versus future. Participants completed age and ethnicity demographics, and then were randomly assigned to either high or lowpower conditions, whereby they were asked to recall and write about a situation in which they had power over others, ("[whereby]...you controlled the ability of another person or persons to get something they wanted, or were in a position to evaluate those individuals"; Galinsky et al., 2003, p. 458) or where others had power over them ("[whereby]...someone had control over your ability to get something you wanted, or was in a position to evaluate you"; p. 458). This manipulation of power was chosen as it has been successfully used in past work (Galinsky et al., 2003; Galinsky, Magee, Inesi, \& Gruenfeld, 2006) and can influence actions unrelated to the power instructions, such as turning off an annoying fan (Galinsky et al., 2003) and intentions to vote (Fast et al., 2009). As such, it was expected to impact another unrelated context, that is, sexism.

Following the power manipulation, participants read four scenarios of sexism (see Appendix) to enhance measurement precision (DeVellis, 2017). Participants were asked to put themselves into the shoes of a fictional woman "Jenna"; however, these scenarios were based on real-world events. The first was based on the experience of a young rape victim (A. W. Stewart, 2014). The second was based on Nobel Prize winner Dr. Tim Hunt's sexist remarks about women in science (Shaw, 2015). The third was based on a request by a student to not work with women, that was honored by a Canadian university (Teitel, 2014). The final scenario was based on the \#CoverTheAthlete social media campaign that highlighted sexism in sport (Ferraras, 2015).

After each scenario, participants reported their perceptions of sexism regarding Jenna's situation and how likely they would be, if in her shoes, to respond with three social media responses. They then completed measures of positive affect and collective action intentions. Upon completion, participants were debriefed.

\section{Measures}

Perceived sexism. To assess whether participants were perceiving enough sexism to warrant intentions of activism (van Zomeren et al., 2008), they responded to: "How fairly is Jenna being treated?"; "How justifiable is Jenna's treatment?"; "How sexist is Jenna's treatment?" using a scale ranging from "not at all" (1) to "extremely" (5). Items were recoded so that higher scores represented higher perceived sexism. The mean across all 12 items (three for each scenario) was used as the overall score $(a=.77)$.

Social media activism. To assess social media activism, participants were asked to put themselves in Jenna's position and to indicate how likely they would be to respond to each scenario with three actions: "use social media (Twitter/Instagram etc.) to spread the word about these kind of issues"; "use social media (Twitter/Instagram etc.) to call the guy out or get back at him"; and, "block/unfollow him in all my social media accounts." Each action was created to reflect a digital form of consensus mobilization. Specifically, the 'spreading the word on social media' item can be seen in movements such as \#MeToo, which sought to call attention and gather support regarding issues of sexual assault (King, 2018) and is one of the most common uses for engaging in activism on social media (Halupka, 2016). 
The 'calling the guy out' item is another form of consensus mobilization, akin trying to influence others' opinions (Halupka, 2016). This kind of social media activism can be seen in movements such as \#DistractinglySexy, whereby thousands of female scientists demonstrated collective outrage by posting job-related photos of themselves accompanied by comments to counter Tim Hunt's depiction of women as distracting and emotional in labs (Shaw, 2015).

Finally, 'unfollowing/unfriending', was chosen as a digital form of boycotting, which has been classified among the range of collective actions (B. Klandermans, van der Toorn, \& van Stekelenburg, 2008), and can be conceptualized as another way to express displeasure and influence others' opinions (Garrett, 1987). Unfollowing/unfriending has become a popular means of conveying disagreement with others' political beliefs (John \& Dvir-Gvirsman, 2015; Rainie \& Smith, 2012) and is perceived as negative by those being unfriended (Bevan, Pfyl, \& Barclay, 2012; Sibona, 2014).

Items were rated on a scale ranging from "not at all likely" (1) to "extremely likely" (5). The mean across all 12 items (three per scenario) was used as the overall social media activism score $(\alpha=.85)$.

Positive affect. Using the positive affect sub-scale from the Positive and Negative Affect Schedule-Expanded Form (Watson \& Clark, 1994), participants were asked to think about what their mood would be like after performing those behaviors, by responding to nine adjectives on a 5-point scale from "not at all (1) to "extremely" (5). The average of all nine items (i.e., active, attentive, alert, determined, enthusiastic, excited, inspired, interested, proud) was used as the overall positive affect score $(\alpha=.85)$.

Collective action intentions. Using a scale ranging from "not at all likely" (1) to "extremely likely" (5), participants indicated how likely they would be to perform 25 collective actions (Foster \& Matheson, 1995). Three items from the original scale were updated $(\alpha=.96)$ to reflect social media forms of collective action (i.e., "I will follow people who talk about women's issues on social media"; "I will pass on information on women's issues using social media"; "I will express myself on social media when something about women's issues upsets me"). However, because these three items potentially shared variance with the social media activism scale, they were deleted, and the analysis was performed on the average of the remaining 22 items measuring offline collective action $(a=.95)$ for the most conservative estimate of the model.

\section{Results}

\section{Sexism Check}

For sexism to have been adequately portrayed, women should report scores above the midpoint of the scale (i.e., 3), and perceive sexism equally across the samples and conditions. A one sample t-test showed that, overall, women rated Jenna's treatment $(M=4.43, S D=0.51)$ as significantly higher than the midpoint, indicating perceived sexism, $t(306)=49.19,95 \% \mathrm{Cl}_{\text {Mean difference }}[1.37,1.48]$. To assess whether sexism was perceived equally across cells, a 2(Sample; MTurk, University) X 2(Condition; Low-power, High-power) ANOVA was conducted. There was no effect of sample, $F(1,303)=0.04, p=.85$, or condition, $F(1,303)=3.08, p=.08$, on perceived sexism, but there was a significant interaction, albeit with a very small partial $\eta^{2}$ of .02 . To investigate what was driving this interaction, simple effects analyses were conducted. The only difference was a significant simple effect of condition on perceived sexism within the university sample, $F(1,303)=10.17, p=.002$, such that those in the low-power condition reported slightly more perceived sexism $(M=4.54, S E=0.05)$ than those in the high-power condition $(M$ $=4.30, S E=0.05)$, albeit again with a small partial $\eta^{2}$ of .03 . Nevertheless, perceived sexism was therefore used as a covariate in the main model.

\section{Power Manipulation Check}

Language, by definition, conveys meaning. As such, the words individuals choose to convey their meanings can provide valuable information about psychological processes (Pennebaker \& Chung, 2007). A particular benefit of using language to measure psychological constructs is that it is considered a more unobtrusive means of examination compared to other forms of measurement (Salicru, 2018; Wolf, Sedway, Bulik, \& Kordy, 2007). For example, one of its strengths over other forms of content analysis is that it relies less on the researcher's 
idiosyncratic perspective to examine content themes, and/or on the subjective opinions of judges to rate those themes. One of its strengths over surveys is that it is less subject to demand characteristics and biases such as social desirability. Moreover, there is accumulating research supporting the use of linguistic markers to predict a variety of psychological constructs (see Tausczik \& Pennebaker, 2010 for a review) such as personality traits (Yarkoni, 2010), well-being (Schwartz et al., 2016), and childhood sexual abuse (Stanton, Meston, \& Boyd, 2017).

As such, to assess the effectiveness of the power manipulation in an unobtrusive manner, women's text responses to the manipulation were analyzed using Linguistic Inquiry and Word Count software (LIWC2015; Pennebaker, Booth, Boyd, \& Francis, 2015), a text analysis program that calculates the percentage of the total number of words for particular word categories. Three different word categories were examined, given empirical support of their relationship to power. Specifically, "Clout" is a summary category, comprised of a variety of word categories produced by LIWC2015 (Pennebaker et al., 2015) whereby higher numbers indicate greater expertise and confidence. "I" words (reflecting self-focused, tentative language) predict low status, whereas "we" words predict high status (Kacewicz, Pennebaker, Davis, Jeon, \& Graesser, 2014).

For the manipulation to have been successful, those in the high-power condition should use more 'clout' and 'we' words, and fewer 'I' words than those in the low-power condition. This would indicate the high-power condition was using more power words in their language, suggesting we successfully manipulated perceptions of power. However, there should be no differences between samples, or any interaction; this would ensure that perceptions of power were perceived equally across the two samples. This was assessed using a 2(Sample; MTurk, University) x 2(Power; Low, High) MANOVA on the 'clout,' I' and 'we' word categories. The multivariate $F$ s for sample, $F(3,301)$ $=1.31, p=.27$ and the interaction, $F(3,301)=0.87, p=.46$ were not significant, but as expected, the effect of condition was significant, $F(3,301)=12.20, p<.001$. Both univariate $F$ 's for 'clout,' $F(1,303)=25.97, p<.001$, partial $\eta^{2}=.079$, and ' $I$ ' words, $F(1,303)=12.22, p<.001$, partial $\eta^{2}=.065$ were significant, such that the those in the highpower condition reported more 'clout' words $(M=39.75, S E=2.16)$ and fewer 'I' words $(M=10.32, S E=0.41)$ than those in the low-power condition $\left(M_{\text {clout }}=24.50, S E=2.10 ; M_{\mathrm{i}}=12.94, S E=0.39\right)$. There were no significant differences in the use of 'we' words across the high $(M=0.39, S E=0.10)$ and low-power $(M=0.42, S E=0.10)$ conditions, $F(1,303)=0.05, p=.82$. Given the success of this power manipulation in other research (e.g., Galinsky et al., 2003; 2006), and the majority of supported manipulation checks in this study, the power manipulation was considered successful.

\section{Data Analysis Plan}

To test hypotheses, Hayes' Process (2018a) custom dialog for SPSS was used. Process provides various preprogrammed statistical models labelled with model numbers (e.g., "Model 1" tests simple moderation). We tested 4 models (Model 18, Model 14, Model 11, Model 7).

Step 1. Because it was of interest to test whether the hypothesized relationships could be generalized beyond a university sample, the first analysis was a test of the equivalency of the theoretical model (Figure 1) across the two samples. This was done using Hayes' Model 18 , which is a model of dual moderated mediation at the second stage of mediation. This model tests whether the indirect effect that is moderated by one independent variable (in this case, power) is further moderated by a second independent variable (in this case, sample). (see Figure 2).

This model produces an "index of moderated moderated mediation" (Hayes, 2018b, p. 20), which, if significant, indicates if power's moderation of the indirect effect of social media activism on collective action intentions through positive affect differs across samples. If the index is not significant, then the moderation of the mediation model by power does not differ across the two samples. As such, it is not appropriate to further probe the two samples separately (Hayes, 2018b), and they can be combined for further testing.

Step 2. This further testing utilized Model 14, which is a model of moderated mediation at the second stage of mediation. This model tests the hypothesis that power moderates the indirect effect of social media activism on collective action intentions through positive affect at the path between positive affect and collective action intentions (Figure 1). This model produces an "index of moderated mediation" (Hayes, 2015); if significant, it indicates that power moderates the mediation model at the second stage of mediation, in which case, the model can be further probed to assess the conditional indirect effects. 


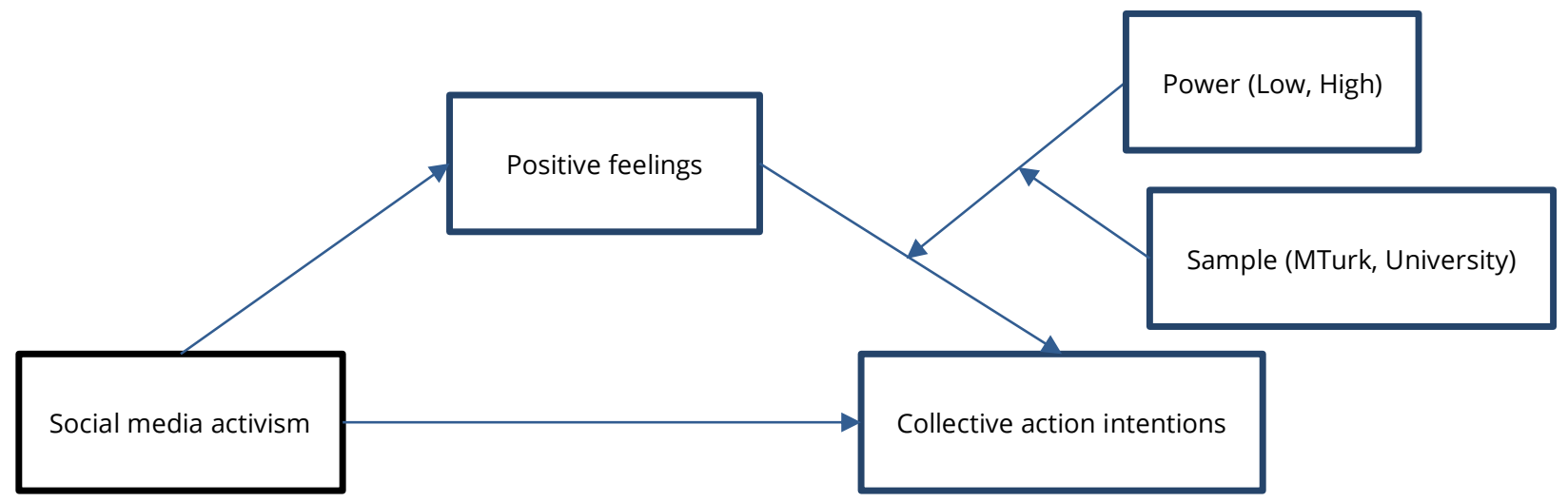

Figure 2. Hypothesized dual moderated mediation model at the second stage of mediation.

Step 3. Because the power manipulation occurred at the beginning of the experiment, it was also necessary to rule out possible competing models, namely that moderation is occurring at the first stage of mediation (between social media activism and positive affect). To do so, steps 1 and 2 of the data analysis plan were repeated, but using Hayes's Models 11 and 7; instead, these models test dual moderated mediation and moderated mediation at the first stage of mediation, respectively (see Figure 3).
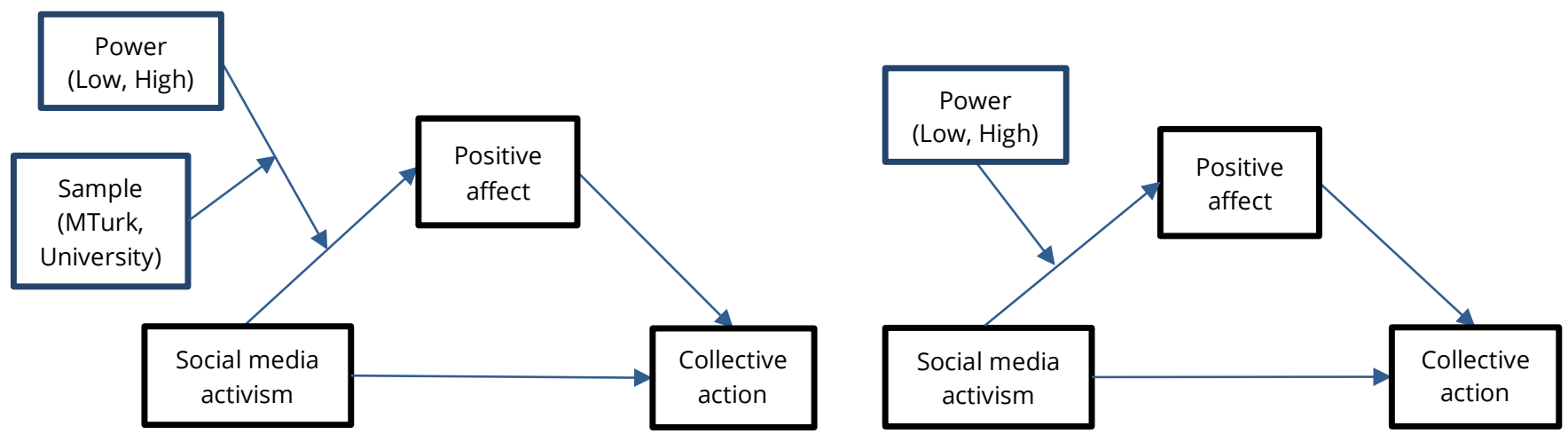

Figure 3. Competing Models: Panel 1 represents Model 11, Dual Moderated Mediation at the first stage of mediation. Panel 2 represents Model 7, Moderated Mediation at the first stage of mediation.

For all models, age and perceived sexism were included as covariates, variables were mean-centered, and unstandardized coefficients are reported. The MTurk sample was coded as 1 and the university sample was coded as 2; the low-power condition was coded as 1 and the high-power condition was coded as 2.

\section{Main Analysis}

Model 18 (see Table 1). The "index of moderated moderated mediation" (Hayes, 2018b), which is the test of whether the moderation of the indirect effect of social media activism by power is further moderated by sample, was tested using a bias-corrected $95 \%$ bootstrap confidence interval based on 5000 samples. The index $(.06, S E=$ .06), was not significant as the confidence interval contained zero, $[-.05, .20]$. As such, the moderation of the 
indirect effect of social media activism by power did not differ across the MTurk and university samples. Given this equivalence, the samples were combined to test the hypothesized model.

Table 1. Summary of Dual Moderated Mediation at the Second Stage of Mediation (Model 18).

\begin{tabular}{lccc}
\hline Predictor & $\boldsymbol{B}$ & SE & CI \\
\hline Outcome: Mediator (Positive Feelings) & & & \\
$\quad$ Social Media Activism & $0.27^{* *}$ & .05 & {$[0.160,0.373]$} \\
Age & 0.00 & .00 & {$[-0.003,0.010]$} \\
Perceived Sexism & -0.01 & .09 & {$[-0.179,0.158]$} \\
Outcome: Collective Action Intentions & & & \\
Age & $-0.02^{* *}$ & .00 & {$[-0.026,-0.009]$} \\
Perceived Sexism & $0.20^{*}$ & .08 & {$[0.036,0.364]$} \\
Positive Feelings & $0.27^{* *}$ & .05 & {$[0.160,0.382]$} \\
Social Media Activism & $0.34 * *$ & .05 & {$[0.229,0.443]$} \\
Power Condition & $0.26 * *$ & .08 & {$[0.093,0.423]$} \\
Sample Type & -0.16 & .12 & {$[-0.392,0.075]$} \\
Positive Feelings X Power Condition & $0.29 * *$ & .08 & {$[0.079,0.505]$} \\
Positive Feelings X Sample Type & -0.09 & .11 & {$[-0.304,0.121]$} \\
Power X Sample Type & 0.18 & .17 & {$[-0.150,0.518]$} \\
Positive Feelings X Power Condition X Sample Type & 0.20 & .22 & {$[-0.208,0.640]$} \\
\hline
\end{tabular}

Note. ${ }^{*} p<.05,{ }^{*} p<.01$. Age and perceived sexism are covariates.

Model 14 (see Table 2). The "index of moderated mediation" (Hayes, 2015), which is the test of whether the indirect effect varies across the power conditions, was tested using a bias-corrected 95\% bootstrap confidence interval based on 5000 samples. The index was $.08(S E=.04)$, and the $\mathrm{Cl}$ did not contain zero $[.02, .14]$, indicating significant moderated mediation, such that the indirect effect increased with power. To probe the moderated mediation (akin to testing simple effects when probing a significant interaction), the conditional indirect effects were also tested with a bias-corrected 95\% bootstrap confidence interval based on 5000 samples. The conditional indirect effect for the low-power condition $(.03, S E=.03)$ was not significant, $95 \% \mathrm{Cl}[-.01, .09]$. However, the index was significant for the high-power condition $(.11, S E=.03), 95 \% \mathrm{Cl}[.06, .18]$, indicating that among those in the high-power condition, the more women endorsed social media activism, the more positive affect they reported $(B=0.27, S E=$ $.06,95 \% \mathrm{Cl}[.16, .37])$, which in turn, predicted stronger collective action intentions $(B=0.41,95 \% \mathrm{Cl}=[.26, .57])$.

Table 2. Summary of Moderated Mediation at the Second Stage of Mediation (Model 14).

\begin{tabular}{lccc}
\hline Predictor & $\boldsymbol{B}$ & $\boldsymbol{S E}$ & $\mathbf{C I}$ \\
\hline Outcome: Mediator (Positive Feelings) & & & \\
$\quad$ Social Media Activism & $0.27 * *$ & .05 & {$[0.160,0.373]$} \\
Age & 0.00 & .00 & {$[-0.003,0.010]$} \\
$\quad$ Perceived Sexism & -0.01 & .09 & {$[-0.179,0.158]$} \\
Outcome: Collective Action Intentions & & & \\
Age & $-0.01 * *$ & .00 & {$[-0.019,-0.007]$} \\
Perceived Sexism & $0.18 *$ & .08 & {$[0.020,0.343]$} \\
Positive Feelings & $0.27 * *$ & .05 & {$[0.160,0.382]$} \\
Social Media Activism & $0.34 * *$ & .05 & {$[0.238,0.449]$} \\
Power Condition & $0.25 * *$ & .08 & {$[0.089,0.418]$} \\
Positive Feelings X Power Condition & $0.29 * *$ & .11 & {$[0.075,0.497]$} \\
\hline
\end{tabular}

Note. ${ }^{*} p<.05,{ }^{*} p<.01$. Age and perceived sexism are covariates. The values for the relationships between the predictors and positive feelings are the same as in Table 1 because moderation is occurring at the second stage of mediation. 
Competing models. Neither the dual moderated mediated model (Model 11; see Table 3), nor the moderated mediation model (Model 7; see Table 4) at the first stage of mediation was significant, as indicated by nonsignificant indices of moderated moderated mediation $(.06, S E=.07,95 \% \mathrm{Cl}[-.05, .21]$ and moderated mediation $(.05, S E=.03,95 \% \mathrm{Cl}[-.01, .11]$, respectively. Thus, neither power condition nor sample type moderated the indirect effect at the first stage of mediation.

Table 3. Summary of Competing Model of Dual Moderated Mediation (Model 11).

\begin{tabular}{|c|c|c|c|}
\hline & $\boldsymbol{B}$ & SE & $\mathbf{C l}$ \\
\hline \multicolumn{4}{|l|}{ Outcome: Positive Feelings } \\
\hline Age & 0.01 & .00 & {$[-0.002,0.015]$} \\
\hline Perceived Sexism & 0.05 & .09 & {$[-0.124,0.230]$} \\
\hline Social Media Activism & $0.27 * *$ & .05 & {$[0.164,0.375]$} \\
\hline Power Condition & $0.22 * *$ & .09 & {$[0.044,0.388]$} \\
\hline Sample Type & 0.10 & .12 & {$[-0.142,0.339]$} \\
\hline Social Media Activism X Power Condition & 0.15 & .11 & {$[-0.058,0.364]$} \\
\hline Social Media Activism X Sample Type & 0.15 & .11 & {$[-0.065,0.372]$} \\
\hline Power Condition X Sample Type & -0.05 & .18 & {$[-0.400,0.298]$} \\
\hline Social Media Activism X Power Condition X Sample Type & 0.22 & .22 & {$[-0.211,0.649]$} \\
\hline \multicolumn{4}{|l|}{ Outcome: Collective Action Intentions } \\
\hline Age & $-0.01 * *$ & .00 & {$[-0.020,-0.008]$} \\
\hline Perceived Sexism & 0.16 & .08 & {$[-0.006,0.321]$} \\
\hline Social Media Activism & $0.35 * *$ & .05 & {$[0.241,0.455]$} \\
\hline Positive Feelings & $0.29 * *$ & .05 & {$[0.177,0.400]$} \\
\hline
\end{tabular}

Note. ${ }^{\star} p<.05,{ }^{\star} * p<.01$. Age and perceived sexism are covariates.

Table 4. Summary of Competing Models of Moderated Mediation (Model 7).

\begin{tabular}{llll}
\hline & $\boldsymbol{B}$ & SE & $\mathbf{C I}$ \\
\hline Outcome: Positive Feelings & & & \\
Age & 0.00 & .00 & {$[-0.002,0.010]$} \\
Perceived Sexism & 0.02 & .09 & {$[-0.144,0.193]$} \\
Social Media Activism & $0.27 * *$ & .05 & {$[0.161,0.375]$} \\
Power Condition & $0.21 * *$ & .09 & {$[0.034,0.375]$} \\
Social Media Activism X Power Condition & 0.16 & .11 & {$[-0.058,0.364]$} \\
Social Media Activism X Sample Type & 0.15 & .11 & {$[-0.044,0.373]$} \\
Outcome: Collective Action Intentions & & & \\
Age & $-0.01 * *$ & .00 & {$[-0.020,-0.008]$} \\
Perceived Sexism & 0.16 & .08 & {$[-0.006,0.321]$} \\
Social Media Activism & $0.35^{* *}$ & .05 & {$[0.241,0.455]$} \\
Positive Feelings & $0.29 * *$ & .05 & {$[0.177,0.400]$} \\
\hline
\end{tabular}

Note. ${ }^{*} p<.05,{ }^{*} p<.01$. Age and perceived sexism are covariates. The values for the relationships between the predictors and collective action intentions are the same as in Table 3 because moderation is occurring at the first stage of mediation.

\section{Discussion}

This study tested whether the effect of social media activism on collective action intentions was mediated by positive affect, and whether this indirect effect was moderated by experimentally manipulated perceived power differences. As expected, this study showed that among those in the high-power condition, the more women endorsed social media activism in response to reading about sexism, the more positive affect they reported, which 
in turn predicted greater collective action intentions. Among those in the low power condition however, the indirect effect was not present.

The fact that the power condition moderated the indirect effect of social media activism on collective action intentions through positive affect is consistent with the literature showing that perceived power stimulates approach-based thoughts and behaviours (e.g., Keltner et al., 2003), and as such, has several theoretical and practical implications. From a theoretical perspective, this finding supports the integration of an individual-level definition of perceived power (having the resources to control outcomes for someone else) with an intergroup phenomenon (collective action). In particular, it suggests another facet that could be introduced into the feedback loops theorized by the DDPM (van Zomeren et al., 2012). As previously noted, the model argues that there are various feedback loops that exist between collective action and its antecedents and consequences; one of these being the degree to which an individual feels they have the resources to cope. The more people feel they have the resources to cope, the more likely they will believe that they can have an impact, which in turn reinforces future collective action (van Zomeren et al., 2012). In line with this, the current study suggests that perceived power may be a useful coping resource that could be incorporated into that feedback loop; those with greater individual feelings of power may feel they have the resources to turn positive post-social media activism feelings into future action.

Moreover, the indirect effect through positive feelings supports the notion that, in contrast to what critics of social media activism argue (e.g., Morozov, 2009), positive feelings do play a role in promoting collective action. Consistent with psychological theories, both about the role of positive affect in general behavior (Skinner, 1971) and collective action specifically (e.g., van Zomeren et al., 2012), feeling good after indicating a willingness to perform low-effort, small-scale action promoted intentions to participate in future, high-effort, larger-scale collective actions. This finding provides empirical support for the potential of social media activism to create larger social change. Anecdotally, several journalists have characterized the \#MeToo social media movement as the impetus for a cultural shift, as well as for larger-scale actions such as the Time's Up Now organization (a legal defense fund to help victims of sexual assault and abuse in the workplace) and Anita Hill's commission on sexual harassment in Hollywood (e.g., Felsenthal, 2018; Garber, 2018; Lin, 2017). Whether or not that is in fact the case, this research provides empirical support for such speculation-under the right conditions (i.e., in this case, perceiving higher power), social media activism can make women feel good, which in turn, may spark larger collective actions. As such, criticisms of social media activism as merely 'feel-good' mechanisms may be less wellfounded than first thought.

From a practical perspective, the effectiveness of the power manipulation (Galinsky et al., 2003) in a context of discrimination and activism is consistent with literature showing that thinking about power can have widereaching effects in unrelated contexts (Fast et al., 2009; Galinsky et al., 2003). Further, the fact that the power manipulation moderated the mediation model equally across the two samples highlights its generalizability outside a university sample, and may have various applications. As this study suggests, it could be a simple yet effective intervention to enhance the outcomes of social media activism-by asking people to envision themselves in a powerful situation, feeling good after social media activism may propel them toward future collective action. It could also be a way of enhancing the extent to which social media activism is positively received by its audience. Research shows that people attribute more positive qualities to powerful people (Georgesen \& Harris, 1998; Humphrey, 1985) and to those with powerful speech styles (Adkins \& Brashers, 1995; Bradac \& Mulac, 1984; Haleta, 1996). As such, asking individuals to recall a high-power situation may positively impact the quality of their social media responses. For example, our current ongoing research is examining whether recalling a high-power experience before constructing a tweet intended to mobilize consensus results in better reception by its audience than a tweet created by those recalling a low-power experience. If so, a more supported tweet may enhance one's sense of group efficacy, another factor that can enhance future collective action (van Zomeren et al., 2012).

Limitations of this study include the lack of additional mediators and moderators. Consistent with the ESIM (Drury \& Reicher, 1999), endorsing social media activism may have also enhanced social identity, which in turn may have promoted greater collective action intentions. For example, when women were asked to tweet about real-world sexist events, with no limitations placed on the content of those tweets, the vast majority of those tweets were focused on collective intent (Foster, 2015). Moreover, online activism enhances the relationship between social 
identity and well-being (Foster, 2019). Thus, consistent with the relationship between offline activism and identity (Drury, Cocking, Beale, Hanson, \& Rapley, 2005; Evripidou \& Drury, 2013), using social media activism may also solidify gender identity, which in turn could enhance collective action intentions. It is equally feasible that social identity could moderate these relationships, however, we did not measure this construct. Given the research on social identity as a buffer for the negative well-being effects of discrimination (e.g., Jetten, Haslam, \& Haslam, 2012), social identity may be another resource that allows individuals to progress social media activism into future collective action, through positive affect.

Another limitation is that this research used collective action intentions as a proxy for performed collective action. Indeed, while it will be invaluable to also examine actual collective action in future research, the use of action intentions does not necessarily discount the potential contribution of findings. According to the theory of reasoned action (Ajzen \& Fishbein, 1980; Fishbein \& Ajzen, 1975), intentions are the proximate precursor of action, making intentions an important aspect of behavior. Since the theory was posed, research has found intentions to be a consistent predictor of action, across a variety of contexts (e.g., health behaviors: Davis, Jackson, Kronenfeld, \& Blair, 1984; everyday behaviours: Madden, Ellen, \& Ajzen, 1992; diet: McDermott et al., 2015; alcohol abuse: Moreno, Mercer, Young, Cox, \& Kerr, 2019; see also Webb \& Sheeran, 2006 for a review of the experimental effects of intentions on action). Even within the context of collective action, intentions to participate predict actual participation (De Weerd \& B. Klandermans, 1999; Kelly \& Breinlinger, 1995; B. Klandermans, 1997), suggesting that intentions are an appropriate proxy for performed behaviour. Moreover, the theory of reasoned action states that perceived behavioral control (i.e., having the necessary resources to enact that behaviour; Ajzen, 1985) has a direct effect on action, as well as an indirect effect on action through behavioral intentions. Several meta-analytic reviews support this hypothesis (Armitage \& Conner, 2001; Godin \& Kok, 1996; Hausenblas, Carron, \& Mack, 1997). As such, given behavioral control and the power manipulation are similar constructs, the patterns observed in this study may be applicable to performed action as well. Nevertheless, future research would be strengthened by also measuring performed collective action.

Future research will also be strengthened by examining additional social groups, given the current study examined only women. For example, because men are less likely to take collective action on behalf of women (e.g., Stake, 2007), and because gender equity would be benefitted if they did so, understanding their relationship with social media and offline activism is also necessary. However, different moderators of this relationship may be relevant for different groups. Feeling powerful may not enhance the relationship between social media activism and offline activism among men as it did for women in this study. Feelings of power have been shown to reduce perspectivetaking and empathy (Galinsky et al., 2006; van Kleef et al., 2008), and men exposed to the same power manipulation used in the current study report higher benevolent sexism than women (Vial \& Napier, 2017). If men who feel powerful are more sexist than women, and less empathetic, they may also be unlikely to act for women. Thus, future research will need to examine other potential motivators for advantaged group members to act on behalf of disadvantaged group members.

Finally, this research operationally defined social media activism as a particular type of activism, namely consensus mobilization techniques occurring in a digital space rather than a physical one. Because consensus mobilization is viewed as a precursor to participation in social movements (e.g., B. Klandermans \& Oegema, 1987; Snow et al., 1986), this may explain why these particular social media actions indirectly predicted future collective action intentions. It remains to be seen whether other forms of social media activism, such as, joining a Facebook group will have the same positive benefits.

Despite limitations however, this research is a first step in showing that the 'slacktivism' criticism may not necessarily be justified. Instead, feeling good after social media activism is not necessarily an end, but a means to an end. And perceived power, which can be used for good, may be simple way to help people increase the effectiveness of their social media activism.

\section{Footnotes}

1. To make data collection for student projects easier, this study (focused on gender discrimination) was combined with separate student project with a distinct theoretical focus (sexual minorities), different questions and scenarios. Qualtrics, the survey software, was programmed to assign the gender discrimination 
questionnaires to heterosexual women, and the other questionnaire to sexual minority women and men, based on self-identification. The data on sexual minorities was passed along to the student, and as such, only the data from the heterosexual women was analyzed for this study.

\section{References}

Adkins, M., \& Brashers, D. E. (1995). The power of language in computer-mediated groups. Management Communication Quarterly, 8, 289-322. https://doi.org/10.1177/0893318995008003002

Ajzen, I. (1985). From intentions to actions: A theory of planned behavior. In J. Kuhland \& J. Beckman (Eds.), Action-control: From cognitions to behavior (pp. 11-39). Heidelberg, Germany: Springer.

Ajzen, I., \& Fishbein, M. (1980). Understanding attitudes and predicting social behavior. Englewood Cliffs, NJ, US: Prentice-Hall.

Armitage, C. J., \& Conner, M. (2001). Efficacy of the Theory of Planned Behaviour: A meta-analytic review. British Journal of Social Psychology, 40, 471-499. https://doi.org/10.1348/014466601164939

Augenbran, E. (2011, September 29). Occupy Wall Street and the limits of spontaneous street protest. The Guardian. Retrieved July 10, 2018 from

http://www.theguardian.com/commentisfree/cifamerica/2011/sep/29/occupy-wall-street-protest

Ayres, M. M., Friedman, C. K., \& Leaper, C. (2009). Individual and situational factors related to young women's likelihood of confronting sexism in their everyday lives. Sex Roles, 61, 449-460. https://doi.org/10.1007/s11199009-9635-3

Bates, L. (2014). Everyday sexism. London, UK: Simon \& Schuster.

Baynard, V. L., Moynihan, M. M., \& Plante, E. G. (2007). Sexual violence prevention through bystander education: An experimental evaluation. Journal of Community Psychology, 35, 463-481. https://doi.org/10.1002/jcop.20159

Becker, J. C., Wright, S. C., Lubensky, M. E., \& Zhou, S. (2013). Friend or ally: Whether cross-group contact undermines collective action depends on what advantaged group members say (or don't say). Personality and Social Psychology Bulletin, 39, 442-455. https://doi.org/10.1177/0146167213477155

Bennett, W. L., \& Segerberg, A. (2012). The logic of connective action: Digital media and the personalization of contentious politics. Information, Communication \& Society, 15, 739-768.

https://doi.org/10.1080/1369118X.2012.670661

Bevan, J. L., Pfyl, J., \& Barclay, B. (2012). Negative emotional and cognitive responses to being unfriended on Facebook: An exploratory study. Computers in Human Behavior, 28, 1458-1464.

https://doi.org/10.1016/j.chb.2012.03.008

Boulianne, S. (2009). Does Internet use affect engagement? A meta-analysis of research. Political Communication, 26, 193-211. https://doi.org/10.1080/10584600902854363

Bradac, J. J., \& Mulac, A. (1984). A molecular view of powerful and powerless speech styles: Attributional consequences of specific language features and communicator intentions. Communication Monographs, 51, 307319. https://doi.org/10.1080/03637758409390204

Brinkman, B. G., \& Rickard, K. M. (2009). College students' descriptions of everyday gender prejudice. Sex Roles, 61, 461-475. https://doi.org/10.1007/s11199-009-9643-3

Brunsting, S., \& Postmes, T. (2002). Social movement participation in the digital age: Predicting offline and online collective action. Small Group Research, 33, 525-554. https://doi.org/10.1177/104649602237169 
Case, A. D., \& Hunter, C. D. (2012). Counterspaces: A unit of analysis for understanding the role of settings in marginalized individuals' adaptive responses to oppression. American Journal of Community Psychology, 50, $257-$ 270. https://doi.org/10.1007/s10464-012-9497-7

Clark, R. (2016). "Hope in a hashtag": The discursive activism of \#WhylStayed. Feminist Media Studies, 16, 788-804. https://doi.org/10.1080/14680777.2016.1138235

Cohen-Chen, S., \& van Zomeren, M. (2018). Yes we can? Group efficacy beliefs predict collective action, but only when hope is high. Journal of Experimental Social Psychology, 77, 50-59. https://doi.org/10.1016/j.jesp.2018.03.016

Conley, T. L. (in press). Hashtag archiving. In D. Agostinho, C. D'Ignazio, A. Ring, N. B. Thylstrup, \& K. Veel (Eds), Uncertain Archives. MIT Press.

Conroy, M., Feezell, J. T., \& Guerrero, M. (2012). Facebook and political engagement: A study of online political group membership and offline political engagement. Computers in Human Behavior, 28, 1535-1546.

https://doi.org/10.1016/j.chb.2012.03.012

Davis, K. E., Jackson, K. L., Kronenfeld, J. J., \& Blair, S. N. (1984). Intent to participate in worksite health promotion activities: A model of risk factors and psychosocial variables. Health Education Quarterly, 11, 361-377.

https://doi.org/10.1177/109019818401100311

De Weerd, M., \& Klandermans, B. (1999). Group identification and political protest: Farmers' protest in the Netherlands. European Journal of Social Psychology, 29, 1073-1095. https://doi.org/10.1002/(SICI)1099-

0992(199912)29:8<1073::AID-EJSP986>3.0.CO;2-K

DeVellis, R. F. (2017). Scale Development (4th ed.). Los Angeles, CA, US: Sage.

Droogendyk, L., Wright, S. C., Lubensky, M., \& Louis, W. R. (2016). Acting in solidarity: Cross-group contact between disadvantaged group members and advantaged group allies. Journal of Social Issues, 72, 315-334. https://doi.org/10.1111/josi.12168

Drury, J., Cocking, C., Beale, J., Hanson, C., \& Rapley, F. (2005). The phenomenology of empowerment in collective action. British Journal of Social Psychology, 44, 309-328. https://doi.org/10.1348/014466604X18523

Drury, J., \& Reicher, S. (1999). The intergroup dynamics of collective empowerment: Substantiating the social identity model of crowd behavior. Group Processes \& Intergroup Relations, 2, 381-402.

https://doi.org/10.1177/1368430299024005

Duggan, M. (2014, October 22). Online harassment. Pew Research Center. Retrieved August 26, 2019 from https://www.pewinternet.org/2014/10/22/online-harassment/

Duggan, M., \& Brenner, J. (2013, February 14). The demographics of social media users-2012. Pew Research Center. Retrieved April 22, 2019 from https://www.pewinternet.org/2013/02/14/the-demographics-of-socialmedia-users-2012/

Duncan, L. E. (1999). Motivation for collective action: Group consciousness as mediator of personality, life experiences, and women's rights activism. Political Psychology, 20, 611-635. https://doi.org/10.1111/0162$895 \times .00159$

Duncan, L. E., \& Stewart, A. J. (2007). Personal political salience: The role of personality in collective identity and action. Political Psychology, 28, 143-164. https://doi.org/10.1111/j.1467-9221.2007.00560.x

Eagle, R. B. (2015). Loitering, lingering, hashtagging: Women reclaiming public space via \#BoardtheBus, \#StopStreetHarassment, and the \#EverydaySexism project. Feminist Media Studies, 15, 350-353.

https://doi.org/10.1080/14680777.2015.1008748 
European Institute for Gender Equality. (2019). Gender equality and youth: Opportunities and risks of digitalisation. Luxembourg, Luxembourg: Publications Office of the European Union. https://doi.org/10.2839/556819

Evripidou, A., \& Drury, J. (2013). This is the time of tension: Collective action and subjective power in the Greek anti-austerity movement. Contention: The Multidisciplinary Journal of Social Protest, 1, 31-51.

https://doi.org/10.3167/cont.2013.010103

Fast, N. J., Gruenfeld, D. H., Sivanathan, N., \& Galinsky, A. D. (2009). Illusory control: A generative force behind power's far-reaching effects. Psychological Science, 20, 502-508. https://doi.org/10.1111/j.1467-9280.2009.02311.x

Fatkin, J.-M., \& Lansdown, T. C. (2015). Prosocial media in action. Computers in Human Behavior, 48, 581-586. https://doi.org/10.1016/j.chb.2015.01.060

Feldman, D. B. (2017, February 17). Why the "Like" button may be killing activism: New findings on slacktivism, politics and self-aggrandizement. Psychology Today. Retrieved July 14, 2018 from

https://www.psychologytoday.com/ca/blog/supersurvivors/201702/why-the-button-may-be-killing-activism

Felsenthal, E. (2018). The choice. Time. Retrieved January 26, 2018 from http://time.com/time-person-of-the-year2017-silence-breakers-choice/

Ferraras, J. (2015, November 6). 'Cover the Athlete' urges media to stop asking sexist questions. The Huffington Post Canada. Retrieved July 15, 2018 from https://www.huffingtonpost.ca/2015/11/06/cover-the-athlete-sexistquestions_n_8483906.html

Fishbein, M., \& Ajzen, I. (1975). Belief, attitude, intention and behavior: An introduction to theory and research. Reading, MA, US: Addison-Wesley.

Foster, M. D., (2013). Everyday confrontation of discrimination: The well-being costs and benefits to women over time. International Journal of Psychological Studies, 5(3), 135-154. https://doi.org/10.5539/ijps.v5n3p135

Foster, M. D. (2015). Tweeting about sexism: The well-being benefits of a social media collective action. British Journal of Social Psychology, 54, 629-647. https://doi.org/10.1111/bjso.12101

Foster, M. D. (2019). "Use it or lose it": How online activism moderates the protective properties of gender identity for well-being. Computers in Human Behavior, 96, 163-173. https://doi.org/10.1016/j.chb.2018.11.044

Foster, M. D., \& Matheson, K. (1995). Double relative deprivation: Combining the personal and political. Personality and Social Psychology Bulletin, 21, 1167-1177. https://doi.org/10.1177/01461672952111005

Funnell, A. (2017, October 25). From slacktivism to 'feel-good' protests, activism is broken: Here's how to fix it. ABC News Online. Retrieved July 14, 2018 from https://www.abc.net.au/news/2017-10-25/activism-is-brokenheres-how-we-fix-it/9077372

Galinsky, A. D., Gruenfeld, D. H., \& Magee, J. C. (2003). From power to action. Journal of Personality and Social Psychology, 85, 453-466. https://doi.org/10.1037/0022-3514.85.3.453

Galinsky, A. D., Magee, J. C., Inesi, M. E., \& Gruenfeld, D. H. (2006). Power and perspectives not taken. Psychological Science, 17, 1068-1074. https://doi.org/10.1111/j.1467-9280.2006.01824.x

Garber, M. (2018, January 2). Is this the next step for the \#MeToo movement? The Atlantic. Retrieved July 15, 2018 from https://www.theatlantic.com/entertainment/archive/2018/01/beyond-metoo-can-times-up-effect-realchange/549482/

Garrett, D. E. (1987). The effectiveness of marketing policy boycotts: Environmental opposition to marketing. Journal of Marketing, 51(2), 46-57. https://doi.org/10.1177/002224298705100204 
Georgesen, J. C., \& Harris, M. J. (1998). Why's my boss always holding me down? A meta-analysis of power effects on performance evaluations. Personality and Social Psychology Review, 2, 184-195.

https://doi.org/10.1207/s15327957pspr0203_3

Gladwell, M. (2010, October 4). Small change: Why the revolution will not be tweeted. The New Yorker. Retrieved June 18, 2018 from https://www.newyorker.com/magazine/2010/10/04/small-change-malcolm-gladwell

Glick, P., Fiske, S. T., Mladinic, A., Saiz, J. L., Abrams, D., Masser, B., . . López-López, W. (2000). Beyond prejudice as simple antipathy: Hostile and benevolent sexism across cultures. Journal of Personality and Social Psychology, 79, 763-775. https://doi.org/10.1037/0022-3514.79.5.763

Godin, G., \& Kok, G. (1996). The theory of planned behavior: A review of its applications in health-related behaviors. American Journal of Health Promotion, 11, 87-98. https://doi.org/10.4278/0890-1171-11.2.87

Gruber, J. E. (1998). The impact of male work environments and organizational policies on women's experiences of sexual harassment. Gender \& Society, 12, 301-320. https://doi.org/10.1177/0891243298012003004

Haleta, L. L. (1996). Student perceptions of teachers' use of language: The effects of powerful and powerless language on impression formation and uncertainty. Communication Education, 45, 16-28.

https://doi.org/10.1080/03634529609379029

Halupka, M. (2016). The rise of information activism: How to bridge dualisms and reconceptualise political participation. Information, Communication \& Society, 19, 1487-1503.

https://doi.org/10.1080/1369118X.2015.1119872

Hausenblas, H. A., Carron, A. V., \& Mack, D. E. (1997). Application of the theories of reasoned action and planned behavior to exercise behavior: A meta-analysis. Journal of Sport and Exercise Psychology, 19, 36-51.

https://doi.org/10.1123/jsep.19.1.36

Hayes, A. F. (2015). An index and test of linear moderated mediation. Multivariate Behavioral Research, 50, 1-22, https://doi.org/10.1080/00273171.2014.962683

Hayes, A. F. (2018a). Introduction to mediation, moderation, and conditional process analysis: A regression-based approach (2nd ed.) New York, NY, US: Guilford Press.

Hayes, A. F. (2018b). Partial, conditional and moderated moderated mediation: Quantification, inference and interpretation. Communication Monographs, 85, 4-40. https://doi.org/10.1080/03637751.2017.1352100

Hornsey, M. J., Blackwood, L., Louis, W., Fielding, K., Mavor, K., Morton, T., ... White, K. M. (2006). Why do people engage in collective action? Revisiting the role of perceived effectiveness. Journal of Applied Social Psychology, 36, 1701-1722. https://doi.org/10.1111/j.0021-9029.2006.00077.x

Humphrey, R. (1985). How work roles influence perception: Structural-cognitive processes and organizational behavior. American Sociological Review, 50, 242-252. https://doi.org/10.2307/2095412

Jackson, S. (2018). Young feminists, feminism and digital media. Feminism \& Psychology, 28, 32-49.

https://doi.org/10.1177/0959353517716952

Jetten, J., Haslam, C., \& Haslam, S. A. (2012). The social cure: Identity, health and well- being. New York, NY, US: Psychology Press.

John, N. A., \& Dvir-Gvirsman, S. (2015) 'I don't like you any more': Facebook unfriending among Israelis during the Israel-Gaza conflict of 2014. Journal of Communication, 65, 953-974. https://doi.org/10.1111/jcom.12188 
Kacewicz, E., Pennebaker, J. W., Davis, M., Jeon, M. \& Graesser, A. C. (2014). Pronoun use reflects standings in social hierarchies. Journal of Language and Social Psychology, 33, 125-143.

https://doi.org/10.1177/0261927X13502654

Kelly, C., \& Breinlinger, S. (1995). Identity and injustice: Exploring women's participation in collective action. Journal of Community \& Applied Social Psychology, 5, 41-57. https://doi.org/10.1002/casp.2450050104

Keltner, D., Gruenfeld, D. H., \& Anderson, C. (2003). Power, approach, and inhibition. Psychological Review, 110, 265-284. https://doi.org/10.1037/0033-295X.110.2.265

King, M. (2018, February 27). Alyssa Milano on what is next for \#MeToo. Forbes. Retrieved July 10, 2018 from https://www.forbes.com/sites/michelleking/2018/02/27/alyssa-milano-on-what-is-next-for-

metoo/\#4ec6a2749e10

Klandermans, B. (1997). The social psychology of protest. Oxford, UK: Blackwell Publishers.

Klandermans, B., \& Oegema, D. (1987). Potentials, networks, motivations and barriers: Steps towards participation in social movements. American Sociological Review, 52, 519-531. https://doi.org/10.2307/2095297

Klandermans, B., van der Toorn, J., van Stekelenburg, J. (2008). Embeddedness and identity: How immigrants turn grievances into action. American Sociological Review, 73, 992-1012.

https://dx.doi.org/10.1177/000312240807300606

Klandermans, P. G. (1984). Mobilization and participation in trade union action: An expectancy-value approach. Journal of Occupational Psychology, 57, 107-120. https://doi.org/10.1111/j.2044-8325.1984.tb00153.x

Lalonde, R. N., Stroink, M. L., \& Aleem, M. R. (2002). Representations and preferences of responses to housing and employment discrimination. Group Processes and Intergroup Relations, 5, 83-102.

https://doi.org/10.1177/1368430202005001808

Lee, Y.-H., \& Hsieh, G. (2013). Does slacktivism hurt activism? The effects of moral balancing and consistency in online activism. In W. E. Mackay, S. Brewster, \& S. Bødker (Eds.), CHI '13: Proceedings of the SIGCHI Conference on Human Factors in Computing Systems (pp. 811-820). New York, NY, USA: ACM Press.

https://doi.org/10.1145/2470654.2470770

Lin, S. (2017, December 6). Anita Hill will lead Hollywood's sexual harassment commission \& make sure \#MeToo brings "real change". Bustle. Retrieved July 15, 2018 from https://www.bustle.com/p/anita-hill-will-lead-

hollywoods-sexual-harassment-commission-make-sure-metoo-brings-real-change-7617678

Linder, C., Myers, J. S., Riggle, C., \& Lacy, M. (2016). From margins to mainstream: Social media as a tool for campus sexual violence activism. Journal of Diversity in Higher Education, 9, 231-244.

https://doi.org/10.1037/dhe0000038

Louis, W. R. (2009). Collective action-and then what? Journal of Social Issues, 65, 727-748.

https://doi.org/10.1111/j.1540-4560.2009.01623.x

Madden, T. J., Ellen, P. S., \& Ajzen, I. (1992). A comparison of the theory of planned behavior and the theory of reasoned action. Personality and Social Psychology Bulletin, 18, 3-9. https://doi.org/10.1177/0146167292181001

McCall, M. (1970). Some ecological aspects of Negro slum riots. In J. R. Gusfield (Ed.), Protest, reform and revolt: A reader in social movements (pp. 345-362). New York, NY, US: Wiley.

McCarthy, J. D., \& Zald, M. N. (1977). Resource mobilization and the social movement: A partial theory. American Journal of Sociology, 82, 1212-1241. https://doi.org/10.1086/226464 
McDermott, M. S., Oliver, M., Simnadis, T., Beck, E. J., Coltman, T., Iverson, D., .. Sharma, R. (2015). The Theory of Planned Behavior and dietary patterns: A systematic review and meta-analysis. Preventative Medicine, 81, 150156. https://doi.org/10.1016/j.ypmed.2015.08.020

Mendes, K., Ringrose, J., \& Keller, J. (2018). \#MeToo and the promise and pitfalls of challenging rape culture through digital feminist activism. European Journal of Women's Studies, 25, 236-246.

https://doi.org/10.1177/1350506818765318

Milošević-Đorđević, J. S., \& Žeželj, I. L. (2017). Civic activism online: Making young people dormant or more active in real life? Computers in Human Behavior, 70, 113-118. https://doi.org/10.1016/j.chb.2016.12.070

Moreno, M. A., Mercer, L., Young, H. N., Cox, E. D., \& Kerr, B. (2019). Testing young adults' reactions to Facebook cues and their associations with alcohol use. Substance Use \& Misuse, 54, 1450-1460.

https://doi.org/10.1080/10826084.2019.1585458

Morozov E. (2009, May 19). The brave new world of slacktivism. Foreign Policy. Retrieved May 18, 2014 from https://foreignpolicy.com/2009/05/19/the-brave-new-world-of-slacktivism/

Mummendey, A., Kessler, T., Klink, A., \& Mielke, R. (1999). Strategies to cope with negative social identity: Predictions by social identity theory and relative deprivation theory. Journal of Personality and Social Psychology, 76, 229-245. https://doi.org/10.1037/0022-3514.76.2.229

Murthy, D., Gross, A., \& Pensavalle, A. (2016). Urban social media demographics: An exploration of Twitter use in major American cities. Journal of Computer-Mediated Communication, 21, 33-49.

https://doi.org/10.1111/jcc4.12144

Olson, M. (1965). The logic of collective action. Cambridge, MA, US.: Harvard University Press.

Pennebaker, J. W., Booth, R. J., Boyd, R. L., \& Francis, M. E. (2015). Linguistic Inquiry and Word Count: LIWC2015. Austin, TX, US: Pennebaker Conglomerates (www.LIWC.net).

Pennebaker, J. W., \& Chung, C. K. (2007). Expressive writing, emotional upheavals, and health. In H. Friedman \& R. Silver (Eds.), Handbook of health psychology (pp. 263-284). New York, NY, US: Oxford University Press.

Pew Research Center (2014a). Social networking fact sheet. Retrieved August 27, 2019 from https://www.pewinternet.org/fact-sheet/social-media/

Postmes, T., \& Brunsting, S. (2002). Collective action in the age of the Internet: Mass communication and online mobilization. Social Science Computer Review, 20, 290-301. https://doi.org/10.1177/089443930202000306

Radke, H. R. M., Hornsey, M. J., \& Barlow, F. K. (2018). Changing versus protecting the status quo: Why men and women engage in different types of action on behalf of women. Sex Roles, 79, 505-

518. https://doi.org/10.1007/s11199-017-0884-2

Rainie, L., and Smith, A. (2012, March 12) Social networking sites and politics. Pew Research Center. Retrieved August 20, 2019 from https://www.pewresearch.org/internet/2012/03/12/social-networking-sites-and-politics/

Salicru, S. (2018, October). Rethinking how to measure authentic leadership-A comparative analysis of leaders' authenticity. Paper presented at the International Leadership Association's 20th Annual Global Conference: Authentic leadership for progress, peace \& prosperity, West Palm Beach, FL, US.

Schrager, L. S. (1985). Private attitudes and collective action. American Sociological Review, 50, 858-859.

https://doi.org/10.2307/2095509 
Schumann, S., \& Klein, O. (2015). Substitute or stepping stone? Assessing the impact of low-threshold online collective actions on offline participation. European Journal of Social Psychology, 45, 308-322.

https://doi.org/10.1002/ejsp.2084

Schumann S., Klein O., \& Douglas K. (2012). Talk to act: How Internet use empowers users to participate in collective actions offline. In M. Bang, \& E. L. Ragnemalm (Eds.), Persuasive technology: Design for health and safety. Paper presented at the 7th International Conference, PERSUASIVE 2012, Linköping, Sweden, June 6-8, 2012 (pp. 79-89). Berlin, Germany: Springer. https://doi.org/10.1007/978-3-642-31037-9_7

Schwartz, H. A., Sap, M., Kern, M. L., Eichstaedt, J. C., Kapelner, A., Agrawal, M., .. Ungar, L. H. (2016). Predicting individual well-being through the language of social media. In R. B. Altman, A. K. Dunker, L. Hunter, M. D. Ritchie, T. A. Murray, \& T. E. Klein (Eds.), Biocomputing 2016: Proceedings of the Pacific Symposium (pp. 516-527). Hackensack, NJ, US: World Scientific.

Shaw, C. (2015, June 11). \#Distractinglysexy Twitter campaign mocks Tim Hunt's sexist comments. The Guardian. Retrieved July 13, 2018 from https://www.theguardian.com/higher-educationnetwork/2015/jun/11/distractinglysexy-twitter-campaign-mocks-tim-hunts-sexist-comments

Sibona, C. (2014). Facebook fallout: The emotional response to being unfriended on Facebook. In Proceedings of the 46th Hawaii International Conference on System Sciences (pp. 3272-3281). Washington, DC, US: IEEE Computer Society.

Skinner, B. F. (1971). Beyond freedom and dignity. New York, NY, US: Knopf.

Smelser, N. J. (1964). Theoretical issues of scope and problems. The Sociological Quarterly, 5, 116-122. https://doi.org/10.1111/j.1533-8525.1964.tb01610.x

Snow, D. A., Rochford, E. B. Jr., Worden, S. K., \& Benford, R. D. (1986). Frame alignment processes, micromobilization and movement participation. American Sociological Review, 51, 464-481.

https://doi.org/10.2307/2095581

Solórzano, D., Ceja, M., \& Yosso, T. (2000). Critical race theory, racial microaggressions, and campus racial climate: The experiences of African American college students. The Journal of Negro Education, 69, 60-73. Retrieved from https://www.jstor.org/stable/2696265

Stake, J. E. (2007). Predictors of change in feminist activism through women's and gender studies. Sex Roles, 57, 43-54. https://doi.org/10.1007/s11199-007-9227-z

Stanton, A. M., Meston, C. M., \& Boyd, R. L. (2017). Sexual self-schemas in the real world: Investigating the ecological validity of language-based markers of childhood sexual abuse. Cyberpsychology, Behavior and Social Networking, 20, 382-388. https://doi.org/10.1089/cyber.2016.0657

Hango, D. (2016). Insights on Canadian society: Cyberbullying and cyberstalking among Internet users aged 15 to 29 in Canada (Catalogue No. 75-006-X). Retrieved August 26, 2019 from https://www150.statcan.gc.ca/n1/pub/75-006x/2016001/article/14693-eng.htm

Statistics Canada. (2018). Just the facts: The gender wage gap and equal pay day, 2018 (Catalogue No. 89-29-0001). Retrieved August 24, 2019 from https://www150.statcan.gc.ca/n1/pub/89-28-0001/2018001/article/00010eng.htm

Stewart, A. L. (2014). The Men's Project: A sexual assault prevention program targeting college men. Psychology of Men \& Masculinity, 15, 481-485. http://dx.doi.org/10.1037/a0033947

Stewart, A. W. (2014, July 18). \#lamJada: When abuse becomes a teen meme. CNN. Retrieved July 15, 2018 from https://www.cnn.com/2014/07/18/living/jada-iamjada-teen-social-media/index.html 
Sutton, J., \& Pollock, S. (2000). Online activism for women's rights. CyberPsychology \& Behavior, 3, 699-706. https://doi.org/10.1089/10949310050191700

Tajfel, H., \& Turner, J. (1986). The social identity theory of intergroup behavior. In S. Worchel \& L. Austin (Eds.), Psychology of intergroup relations (pp. 7-24). Chicago, IL, US: Nelson-Hall.

Tausczik, Y. R., \& Pennebaker, J. W. (2010). The psychological meaning of words: LIWC and computerized text analysis methods. Journal of Language and Social Psychology, 29, 24-54.

https://doi.org/10.1177/0261927X09351676

Teitel, E. (2014, January 17). Why people of faith should be angry with York University. Maclean's. Retrieved July 15, 2018 from https://www.macleans.ca/education/university/why-people-of-faith-should-be-angry-with-yorkuniversity/

Tilly, C. (1978). From mobilization to revolution. Reading, MA, US: Addison-Wesley.

Tufekci, Z., \& Wilson, C. (2012). Social media and the decision to participate in political protest: Observations from Tahrir square. Journal of Communication, 62, 363-379. https://doi.org/10.1111/j.1460-2466.2012.01629.x

Twenge, J. M. (2017). iGen: Why today's super-connected kids are growing up less rebellious, more tolerant, less happy and completely unprepared for adulthood. New York, NY, US: Simon \& Schuster.

Vaccari, C., Valeriani, A., Barberá, P., Bonneau, R., Jost, J. T., Nagler, J., \& Tucker, J. A. (2015). Political expression and action on social media: Exploring the relationship between lower- and higher-threshold political activities among Twitter users in Italy. Journal of Computer-Mediated Communication, 20, 221-239.

https://doi.org/10.1111/jcc4.12108

van Kleef, G. A., Oveis, C., van der Löwe, I., LuoKogan, A., Goetz, J., \& Keltner, D. (2008). Power, distress and compassion: Turning a blind eye to the suffering others. Psychological Science, 19, 1315-1322.

https://doi.org/10.1111/j.1467-9280.2008.02241.x

van Zomeren, M., \& lyer, A. (2009). Introduction to the social and psychological dynamics of collective action. Journal of Social Issues, 65, 645-660. https://doi.org/10.1111/j.1540-4560.2009.01618.x

van Zomeren, M., Leach, C. W., \& Spears, R. (2012). Protesters as "passionate economists": A dynamic dual pathway model of approach coping with collective disadvantage. Personality and Social Psychology Review, 16, 180199. https://doi.org/10.1177/1088868311430835

van Zomeren, M., Postmes, T., \& Spears, R. (2008). Toward an integrative social identity model of collective action: A quantitative research synthesis of three socio-psychological perspectives. Psychological Bulletin, 134, 504-535. https://doi.org/10.1037/0033-2909.134.4.504

Vial, A. C., \& Napier, J. L. (2017). High power mindsets reduce gender identification and benevolent sexism among women (but not men). Journal of Experimental Social Psychology, 68, 162-170.

http://dx.doi.org/10.1016/j.jesp.2016.06.012

Vitak, J., Zube, P., Smock, A., Carr, C. T., Ellison, N., \& Lampe, C. (2011). It's complicated: Facebook users' political participation in the 2008 election. Cyberpsychology, Behavior and Social Networking, 14, 107-114.

https://doi.org/10.1089/cyber.2009.0226

Watson, D., \& Clark, L. A. (1994). The PANAS-X: Manual for the positive and negative affect scale - Expanded form. University of lowa, lowa City, IA, US. https://doi.org/10.17077/48vt-m4t2 
Webb, T. L., \& Sheeran, P. (2006). Does changing behavioral intentions engender behavior change? A metaanalysis of the experimental evidence. Psychological Bulletin, 132, 249-268. https://doi.org/10.1037/00332909.132.2.249

Weick, M., \& Guinote, A. (2018). When subjective experiences matter: Power increases reliance on the ease of retrieval. Journal of Personality and Social Psychology, 94, 956-970. https://doi.org/10.1037/0022-3514.94.6.956

White, A. M. (2006). Racial and gender attitudes as predictors of feminist activism among self-identified African American feminists. Journal of Black Psychology, 32, 455-478. https://doi.org/10.1177/0095798406292469

Williams, S. (2015). Digital defense: Black feminists resist violence with hashtag activism. Feminist Media Studies, 15, 341-344. https://doi.org/10.1080/14680777.2015.1008744

Williams, R., \& Wittig, M. A. (1997). "I'm not a feminist, but...": Factors contributing to the discrepancy between pro-feminist orientation and feminist social identity. Sex Roles, 37, 885-904. https://doi.org/10.1007/BF02936345

Willingham, A. J. (2018, March 26). Slacktivism is over: The \#NeverAgain movement is about what's next. CNN. Retrieved April 20, 2019 from https://www.cnn.com/2018/03/25/us/march-for-our-lives-slacktivismtrnd/index.html

Wolf, M., Sedway, J., Bulik, C. M., \& Kordy, H. (2007). Linguistic analyses of natural written language: Unobtrusive assessment of cognitive style in eating disorders. International Journal of Eating Disorders, 40, 711-717. https://doi.org/10.1002/eat.20445

Wright, S. C. (2009). The next generation of collective action research. Journal of Social Issues, 65, 859-879. https://doi.org/10.1111/j.1540-4560.2009.01628.x

Wright, S. C. \& Lubensky, (2009). The struggle for social equality: Collective action versus prejudice reduction. In S. Demoulin, J. P. Leyens, \& J. F. Dovidio (Eds.), Intergroup misunderstandings: Impact of divergent social realities (pp. 291-310). New York, NY, US: Psychology Press.

Wright, S. C., Taylor, D. M., \& Moghaddam, F. M. (1990). Responding to membership in a disadvantaged group: From acceptance to collective protest. Journal of Personality and Social Psychology, 58, 994-1003. https://doi.org/10.1037/0022-3514.58.6.994

Yarkoni, T. (2010). Personality in 100,000 words: A large-scale analysis of personality and word use among bloggers. Journal of Research in Personality, 44, 363-373. https://doi.org/10.1016/j.jrp.2010.04.001

\section{Appendix}

\section{Sexism Scenarios}

1. Jenna has been dating a guy for a few months. They're at the point now where she really trusts him and feels comfortable with him. So, when he asks her for some sexy pictures to take with him on holiday, she thinks its sweet that he's going to miss her so much, and sends them. The next day, she wakes up to naked pictures of her all over Twitter and Instagram.

2. Jenna is studying Health Sciences, a gateway to medical school. She and her workgroup are studying for the MCAT (a standardized test necessary for medical school) and they're all discussing what kind of medicine they'd like to pursue. Jenna says she's interested in Neurology and a male group member responds, "Yeah right, this isn't 'Grey's Anatomy' Jenna! Patients like their women doctors doing what they know best-lady parts!' The rest of the group laughs along.

3. Jenna is taking a course in which group work is required. However, a male in the group has requested that Jenna be put into another group because talking to women is against his religion. 
4. Jenna is playing a pick-up basketball game with a bunch of guys; she is the only female on the team. The guys wouldn't pass the ball to her or even look at her. Someone yells, "Get the girl off the court!"

\author{
Correspondence to: \\ Mindi Foster \\ Department of Psychology \\ 75 University Avenue West \\ Waterloo, Ontario \\ $\mathrm{N} 2 \mathrm{~L} 3 \mathrm{C} 5$ \\ Canada \\ Email: mfoster(at)wlu.ca
}

Editorial record: First submission received on July 19, 2018. Revisions received on May 3, 2019 and September 1, 2019. Accepted for publication on October 29, 2019.

Editor in charge: Michel Walrave

\title{
About Authors
}

Mindi D. Foster, Ph.D. is an Associate Professor in the Psychology department at Wilfrid Laurier University. Dr. Foster heads the iWiser Lab (Inequality: Women's Individual and Social Empowerment Responses) lab (mindifoster.com) which examines how women experience, and respond to gender discrimination. Her research examines how women's coping strategies, collective action and social media activism responses to gender discrimination affect their well-being.

Eden Hennessey, Ph.D. researches and mobilizes knowledge related to diversity promotion and discrimination reduction. Some of her recent work assesses the consequences of confronting gender bias in science, technology, engineering, and math (STEM). Dr. Hennessey advocates for equity and inclusion on university campuses, and combines arts with data to impact world-wide audiences. She is deeply committed to her work as the Manager of the Student Centre for Equity, Diversity, and Inclusion at Wilfrid Laurier University and as the Research and Programs Director of the Laurier Centre for Women in Science.

Benjamin T. Blankenship, Ph.D. is an Assistant Professor of Psychology at James Madison University in Harrisonburg, VA. He recently received his Ph.D. in Personality and Social Context Psychology from The University of Michigan. His current research examines the effects of identity, identity dimensionality, and other individual differences on the socio-political engagement (voting, activism, etc.) and inclusion of various minorities in society, with a special focus on sexual and gender minorities and poor and working-class people, as well as other identities/statuses that are connected to these.

Abigail Stewart, Ph.D. is Sandra Schwartz Tangri Distinguished University Professor of Psychology and Women's Studies at UM. She served as director of the UM ADVANCE Program from 2001-2016, and has held other administrative positions at Michigan. She holds degrees from Wesleyan University, London School of Economics, and Harvard University. Her current research focuses on academic and life experiences related to race, class and gender, and on political attitudes and activism. 